\title{
Higher prevalence of smoking and lower BMI, waist circumference, cholesterol and triacylglyceride levels in Prague's homeless compared to a majority of the Czech population
}

\author{
Dana Kubisová*1, Věra Adámková2, Věra Lánská², Pavel Dlouhý1, \\ Jolana Rambousková ${ }^{1}$ and Michal Anděl ${ }^{1}$
}

Address: ${ }^{1}$ Department of Nutrition, Third Faculty of Medicine, Charles University in Prague, Ruská 87, Prague 10, 100 00, Czech Republic and ${ }^{2}$ Institute of Clinical and Experimental Medicine, Vídeňská 1958/9, Prague 4, 140 21, Czech Republic

Email: Dana Kubisová* - dana.kubisova@lf3.cuni.cz; Věra Adámková - vera.adamkova@medicon.cz; Věra Lánská - vela@medicon.cz; Pavel Dlouhý - pavel.dlouhy@lf3.cuni.cz; Jolana Rambousková - jolana.rambouskova@lf3.cuni.cz; Michal Anděl - andel@fnkv.cz

* Corresponding author

Published: 5 April 2007

BMC Public Health 2007, 7:5 I doi:I0.II86/I47|-2458-7-5I
Received: 9 February 2006

Accepted: 5 April 2007

This article is available from: http://www.biomedcentral.com/I47I-2458/7/5 I

(c) 2007 Kubisová et al; licensee BioMed Central Ltd.

This is an Open Access article distributed under the terms of the Creative Commons Attribution License (http://creativecommons.org/licenses/by/2.0), which permits unrestricted use, distribution, and reproduction in any medium, provided the original work is properly cited.

\begin{abstract}
Background: Homeless people have higher morbidity and mortality rates than the general population. Research has shown that cardiovascular disease is the leading cause of death in older homeless adults. This study was undertaken to describe the prevalence of cardiovascular risk factors in the homeless population in Prague.

Methods: Data was obtained from a cross-sectional study carried out in 2003. Body mass index (BMI), waist circumference (WC), total cholesterol (TC), triacylglycerides (TAG) and smoking habits were assessed. The homeless participants in the study were recruited from a homeless center run by a Prague charitable organization called Naděje ("Hope") and at Prague's main railway station. Most participants were assessed at the Naděje center (I34 persons) while the rest were assessed at Prague's Bulovka University Hospital (67 persons).

Results: A total of 201 homeless (174 males and 27 females) aged $19-70$ years were examined. Mean values of BMI, WC, TC and TAG in homeless men and women were within normal limits. Compared with the majority of the Czech population, the homeless had significantly lower mean levels of TC and TAG and lower BMl and WC values. When compared to the majority of the Czech population, the incidence of smoking among the homeless was significantly higher. Among smokers in both populations, no differences were found in the number of cigarettes smoked per day.

Conclusion: Classical cardiovascular risk factors such as TC, TAG, BMI and WC, are significantly lower in Prague's homeless minority than in the majority of the Czech population. However, the prevalence of smoking is much higher in the homeless population.
\end{abstract}

\section{Background}

Awareness of the homeless problem, in the Czech Republic, began to rise, following the overthrow of the commu- nistic regime in 1989. It is estimated that between 35,000 to 75,000 Czechs are homeless [1]. Prague, as the capital of the Czech Republic and its most prosperous region, 
naturally attracts large numbers of homeless. In 2004, a field census of visible homelessness (defined by FEANTSA as rooflessness - without shelter, and houselessness temporary institutional shelters) was carried out by Prague charitable organizations. A total of 3,096 homeless people were identified in Prague, 14\% of which were women [2].

The number of homeless has increased recently. As a result, a growing body of research has focused on this disadvantaged group. Charitable organizations working with homeless people have started to investigate different aspects of the homeless lifestyle, paying particular attention to their socio-economic background and mental health. In 2004, our team published a study on the mental health of the Czech homeless population [3]. Trnka et al. performed a preventive survey regarding the prevalence of tuberculosis in the Czech homeless community [4]. However, few studies have addressed the cardiovascular health of the Czech homeless population, even though cardiovascular diseases are the leading causes of death in the Czech Republic (52.5\% in 2003) [5].

Research has shown that homeless individuals have both higher morbidity and mortality rates than the general population [6] and that cardiovascular disease is the leading cause of death in the elderly homeless [7]. Previous studies of cardiovascular risk factors in homeless populations focused either on isolated risk factors [8-12] or on providing a comprehensive risk profile $[13,14]$. However, these earlier studies were focused on homelessness in Western Europe or North America. Countries in those studies have different socio-economic and political backgrounds and have a much longer history in dealing with the problems of the homeless than has the Czech Republic. Our objective is to describe the prevalence of some of the major cardiovascular risk factors, namely high total cholesterol and triacylglyceride levels, smoking and obesity in those members of Prague's homeless community, that utilize local charitable organizations, and to make comparisons between this group and the general Czech population.

\section{Methods \\ Sampling frame and subjects}

A cross-sectional study of Prague's homeless population was conducted over a period of eight months in 2003. The study was carried in cooperation with Naděje ("Hope"), one of the most important day centers for homeless people in Prague. Assessments of study participants were conducted at either the Naděje Bolzanova street center, or at Prague's Bulovka University Hospital. Body mass index (BMI), waist circumference (WC), total cholesterol (TC), triacylglycerides (TAG), smoking habits and socio-demographic data were assessed.
A total of 201 homeless ( $86.6 \%$ men, $13.4 \%$ women), out of 217 recruited, participated in the study. Fifteen people were excluded from the study because of regular drug abuse. And one additional person was excluded because of a medical condition that precluded reliable anthropometry. Two-thirds of the homeless participants were recruited and examined at the Naděje day center (134); the remaining third of participants were recruited at Prague's main railway station (67) and examined at Prague Bulovka University Hospital. Participants in this second, smaller group were recruited with the aid of staff from Naděje and street workers at the main railway station. It was hoped that the homeless participants recruited from the railway station would represent a sample with little or no contact with charitable organizations, and as such, would provide data on those living completely unassisted. However, our assessment revealed that all recruited participants utilized Prague's charitable organizations to some extent.

Each homeless person who attended the Naděje day center was informed about the possibility of participating in the study. All those that volunteered and who met the inclusion criteria were examined. No information was gathered regarding those who did not volunteer to participate. Each study participant received a food voucher, valued at 100 CZK (approx. 3 Euros). This was a welcome incentive and much appreciated by the participants.

Each participant of the study was required to give their written consent. The study was approved by the ethical committee of the Third Faculty of Medicine, Charles University, Prague.

\section{Anthropometry and biochemistry}

Anthropometric variables including height, weight and waist circumference were taken. Both men and women were weighed in light-weight clothing and without shoes. Measurements were taken to the nearest $0.5 \mathrm{~kg}$. Weights were obtained using an electronic platform scale (SOEHNLE) with an accuracy of $\pm 100 \mathrm{~g}$. Weight values were adjusted for clothing. Height was recorded to the nearest $0.5 \mathrm{~cm}$. Height and weight values were used to determine body mass index (BMI) $\left[\mathrm{kg} / \mathrm{m}^{2}\right]$. BMIs were evaluated based on the 1995 World Health Organization (WHO) interpretation [15]. Waist circumference (WC) was measured, at the narrowest part of the waist, with a plastic tape, to the nearest $0.1 \mathrm{~cm}$. Abdominal obesity was defined as having a waist circumference greater than 102 $\mathrm{cm}$ in men and greater than $88 \mathrm{~cm}$ in women [16].

Venous blood samples, taken from the cubital vein, were used to determine total cholesterol (TC) and triacylglyceride (TAG) levels. All samples were tested at an accredited 
laboratory. Values were evaluated using Guidelines of the European Society of Cardiology 2003 [17].

\section{Data comparison}

The homeless sample was compared with a representative sample of the general Czech population. A survey of cardiovascular risk factors in the general Czech population was conducted in 2000/2001 in nine districts of the country, involving a random sample of $1 \%$ of the population (sample age range: 25 to 64 years) [18]. For comparisons of the two populations, we used only those homeless participants that fit the age profile of the above mentioned sample - this meant using only 162 of 174 males and 24 of 27 females. Additionally, from the group that fit the age profile, some participants were eliminated prior to making educational comparisons. We decided to exclude the only male with a university education and compare only men having primary and secondary educations. A similar rational was used to exclude the two females having a secondary education. As a result, only females with primary educations were compared. Data were adjusted for age.

\section{Statistical analysis}

Data were processed using SPSS software (Statistical Package for the Social Science) for Windows, version 12 and Epi Info, version 3.3. All group data are presented as the mean (standard deviation, SD). Data comparison was done using the t-test, $\chi^{2}$ test, logistic regression and ACNOVA for age and sex adjustment.

\section{Results}

The total number of homeless subjects in the study was 201. One hundred and seventy-four males, with a mean age of 42 (SD: 10.9) years (range: 19 to 70 years), and 27 females, with a mean age of 40 (SD: 9.4) years (range: 23 to 55 years). The mean period of homelessness was 2.2 years for men and 2.3 years for women. Most of the study participants $(79 \%)$ were homeless for less than three years. Long-term homelessness ( $>7$ years) was found in only $8 \%$ of the male participants and in $11 \%$ of the female participants. Men were more educated than women: $78 \%$ of homeless men had completed secondary school, compared to only $33 \%$ of homeless women, for whom primary education was most common (63\%). The majority of the participants were Czech nationals (92\%). When asked about their most important food sources (using questions with multiple choice answers), most study participants reported charities (76\% men, 74\% women) and supermarkets ( $77 \%$ men, $44 \%$ women).

Mean values of BMI, waist circumference, total cholesterol and triacylglycerides were within normal limits (Table 1). Prevalence of being overweight and obese (BMI $\geq 25 \mathrm{~kg} /$ $\mathrm{m}^{2}$ ) in homeless men and women was similar (39\% men, $33 \%$ women). However, obese homeless women tended to be at the higher end of the scales (Fig. 1). The prevalence of increased waist circumference $(94-102 \mathrm{~cm}$ in men, $80-88 \mathrm{~cm}$ in women) and very high waist circumference (i.e. abdominal obesity, WC greater than $102 \mathrm{~cm}$ for men and greater than $88 \mathrm{~cm}$ for women) in the study participants is presented in Fig. 2. Figure 3 shows the prevalence of increased total cholesterol $(>5 \mathrm{mmol} / \mathrm{l})$ and triacylglyceride levels $(>1.7 \mathrm{mmol} / \mathrm{l})$. The percentage of cigarette smokers among the homeless was extremely high: $91.4 \%$ of the men and $77.8 \%$ of the women reported they smoke cigarettes. Mean lifetime exposure was $22 \pm 10.4$ years for men and $23 \pm 7.7$ years for women; men smoked, on average, 17 , and women 14 cigarettes per day. A comparison of the mean values of cardiovascular risk factors including smoking, between the homeless population and the general Czech population, is presented in Table 2. The prevalence of cardiovascular risk factors is compared in Table 3. With the exception of smoking, all risk factors were significantly lower and less common in the homeless participants.

\section{Discussion}

Cardiovascular disease is the major cause of premature death in most European populations, and it is the leading cause of death in the Czech population as well. Our study is the first one to assess cardiovascular risk factors in a sample of Prague's homeless adult population which utilize charitable organizations as part of their lifestyle. We found the prevalence of smoking to be significantly higher in homeless men $(93 \%)$ and women $(83 \%)$ compared to the general Czech population, men $38 \%$ and women $35 \%$. The percentage of homeless that smoke is almost 3 times that of the general population. The homeless tended to have smoked longer; however, the number of cigarettes smoked per day didn't statistically differ from the figure for the general population. A high prevalence of smoking in homeless populations has also been found by other authors $[11,13,14,19,20]$, however none of the reported levels were as extreme as what we found in our study participants. Smoking is associated with a lower socioeconomic status [21] and a lower degree of education [22]. Additionally, the prevalence of nicotine dependence among alcohol or other substance abusers is extremely high [23] and the high degree of alcohol and drug use/ abuse among the homeless is well documented $[11,24,25]$. The higher incidence of smoking in our study participants may be attributable to stress induced by the homeless lifestyle or substance abuse. Additionally, many homeless engage in alternative smoking behaviors, such as smoking discarded cigarette butts and used filters that increase the potential for toxin and infectious agent intake [26].

Hypercholesterolemia and hypertriglyceridemia were significantly lower in the homeless compared to the majority 
Table I: Anthropological and biological indicators in the homeless sample

\begin{tabular}{lll}
\hline Characteristic & $\begin{array}{l}\text { Men, } \mathbf{n}=\mathbf{~ I 7 4} \\
\text { mean }(\mathrm{SD})\end{array}$ & $\begin{array}{l}\text { Women, } \mathbf{n}=\mathbf{2 7} \\
\text { mean }(\mathrm{SD})\end{array}$ \\
\hline Waist circumference $(\mathrm{cm})$ & $88.0(\mathrm{I} 0.5)$ & $78.6(1 \mathrm{I} .0)$ \\
Body mass index $\left(\mathrm{kg} / \mathrm{m}^{2}\right)$ & $24.3(3.9)$ & $24.1(5.0)$ \\
Total cholesterol $(\mathrm{mmol} / \mathrm{l})$ & $4.6(0.9)$ & $4.8(0.9)$ \\
Triacylglycerides $(\mathrm{mmol} / \mathrm{l})$ & $1.2(0.9)$ & $1.0(0.3)$ \\
\hline
\end{tabular}

of the Czech population. This may be a result of decreased accessibility to food, and/or (somewhat more questionable), higher physical activity levels (associated with the homeless lifestyle) compared to the general population. However, an earlier study by Luder et al. [27] showed a high prevalence of hypercholesterolemia (92\% above $5.17 \mathrm{mmol} / \mathrm{l}$ ) and also high intakes of saturated fat and cholesterol among the homeless in New York City, however, this might be due to a different diet profile. Unfortunately, dietary intake was not a subject of our study, and therefore its role in our participants remains speculative. Further research needs to be done to investigate this connection.

The homeless were significantly less likely to be overweight or obese $\left(\mathrm{BMI} \geq 25 \mathrm{~kg} / \mathrm{m}^{2}\right)$ than the general Czech population. Our results document a lower prevalence of overweight and obesity than previous studies. Lee et al. found $46 \%$ of Toronto's homeless adults to be either overweight or obese [14]. An even greater prevalence (54.5\%) was documented by Luder et al. [27]. The prevalence of obesity in homeless men and women was similar; how- ever, obese homeless women tended to have a higher degree of obesity and also a higher prevalence of abdominal obesity. This could be related to the fact that mental problems (depressions and anxiety) are more frequent in women than in men [3], which is often coupled with higher alcohol consumption and its concomitant caloric intake.

In addition, waist circumference was assessed as an indicator of abdominal obesity and as such, a risk factor for cardiovascular diseases. The prevalence of abdominal obesity was much lower in the homeless than in the general population. It has been shown that abdominal obesity is positively correlated with the intake of total fat [28] and smoking, and negatively correlated with protein intake [29]. A nutritional survey of the daily consumption of the homeless would go a long way towards verifying this assumption.

\section{Conclusion}

We conclude that the Prague homeless population (at least those meeting our inclusionary criteria) has a higher

Table 2: Comparison of mean values of the cardiovascular risk factors among the homeless and the general Czech population

\begin{tabular}{|c|c|c|c|}
\hline Cardiovascular risk factors in men & $\begin{array}{l}\text { Homeless, } \mathbf{n}=162 \\
\text { mean (SD) }\end{array}$ & $\begin{array}{l}\text { General population, } \mathbf{n}=\mathbf{I}, 408 \\
\text { mean (SD) }\end{array}$ & p value \\
\hline age (yrs) & $43.0(9.7)$ & $46.5(10.9)$ & $<0.001$ \\
\hline BMI $\left(\mathrm{kg} / \mathrm{m}^{2}\right)$ & $24.4(3.9)$ & $28.2(4.4)$ & $<0.001$ \\
\hline waist circumference $(\mathrm{cm})$ & $88.1(10.5)$ & $97.3(11.9)$ & $<0.001$ \\
\hline total cholesterol (mmol/l) & $4.6(0.9)$ & $5.9(1.1)$ & $<0.001$ \\
\hline triglycerides $(\mathrm{mmol} / \mathrm{l})$ & $1.2(0.9)$ & $2.0(1.4)$ & $<0.001$ \\
\hline length of smoking (yrs) & $22.6(9.9)(n=140)$ & $24.8(10.7)(n=539)$ & n.s. \\
\hline number of cigarettes per day & $17.3(9.2)(n=149)$ & $17.2(8.8)(n=505)$ & n.s. \\
\hline Cardiovascular risk factors in women & $\begin{array}{l}\text { Homeless, } \mathbf{n}=\mathbf{2 4} \\
\text { mean (SD) }\end{array}$ & $\begin{array}{l}\text { General population, } \mathbf{n}=\mathbf{5 4 3} \\
\text { mean (SD) }\end{array}$ & p value \\
\hline age (yrs) & $40.1(8.8)$ & $42.4(8.1)$ & n.s. \\
\hline BMI $\left(\mathrm{kg} / \mathrm{m}^{2}\right)$ & $24.3(5.2)$ & $27.2(5.6)$ & $<0.05$ \\
\hline waist circumference $(\mathrm{cm})$ & $78.3(11.4)$ & $83.7(13.0)$ & $<0.05$ \\
\hline total cholesterol (mmol/l) & $4.9(0.8)$ & $5.7(I . I)$ & $<0.001$ \\
\hline triglycerides $(\mathrm{mmol} / \mathrm{l})$ & $1.0(0.3)$ & $1.4(0.8)$ & $<0.001$ \\
\hline length of smoking (yrs) & $24.2(6.9)(n=17)$ & $20.3(8.4)(n=192)$ & 0.07 \\
\hline number of cigarettes per day & $13.7(8.1)(\mathrm{n}=20)$ & $11.7(6.4)(n=177)$ & n.s. \\
\hline
\end{tabular}

$P$ values hold after the adjustment for age 
Table 3: Comparison of prevalence of the cardiovascular risk factors among the homeless and the general Czech population, (\%)

\begin{tabular}{|c|c|c|c|c|c|}
\hline \multirow[t]{2}{*}{ Cardiovascular risk factors } & \multicolumn{2}{|c|}{ Homeless population } & \multicolumn{2}{|c|}{ General Czech pop. } & \multirow[t]{2}{*}{ p value } \\
\hline & men $n=162$ & women $n=24$ & men $n=1408$ & women $n=543$ & \\
\hline $\mathrm{BMI} \geq 25 \mathrm{~kg} / \mathrm{m}^{2}$ & 41 & 33 & 75 & 60 & $<0.001$ \\
\hline Abdominal obesity, men $(\mathrm{WC}>102 \mathrm{~cm})$ & 6 & & 31 & & $<0.001^{*}$ \\
\hline Abdominal obesity, women (WC $>88 \mathrm{~cm}$ ) & & 21 & & 31 & n.s.* \\
\hline Total cholesterol $\geq 5 \mathrm{mmol} / \mathrm{l}$ & 33 & 38 & 80 & 72 & $<0.001$ \\
\hline Triacylglycerides $\geq 1.7 \mathrm{mmol} / \mathrm{l}$ & 15 & 0 & 48 & 23 & $<0.001$ \\
\hline Active smokers & 93 & 83 & 38 & 35 & $<0.001$ \\
\hline
\end{tabular}

$P$ values hold after the adjustment for age and sex

*Abdominal obesity was evaluated for each sex separately because of different cut-off points.

In this case, $\mathrm{p}$ values are age adjusted only.

prevalence of smoking than the general Czech population. On the other hand, their lifestyle appears to result in lower BMIs, waist circumference, total cholesterolaemia and triglyceridaemia. It is not certain whether these results can be generalized to the entire homeless population. The participants in our study group consisted of homeless utilizing the services of charitable organizations, and, therefore, may not fully represent the entire homeless population. However, it is this particular subgroup of the homeless that is most likely to benefit from preventive measures and interventions, and for this reason, it repre- sents an important subpopulation of the homeless community.

To reduce smoking in the homeless community will require intervention. However, any truly effective intervention program will require political and socioeconomic changes.

\section{Competing interests}

The author(s) declare that they have no competing interests.

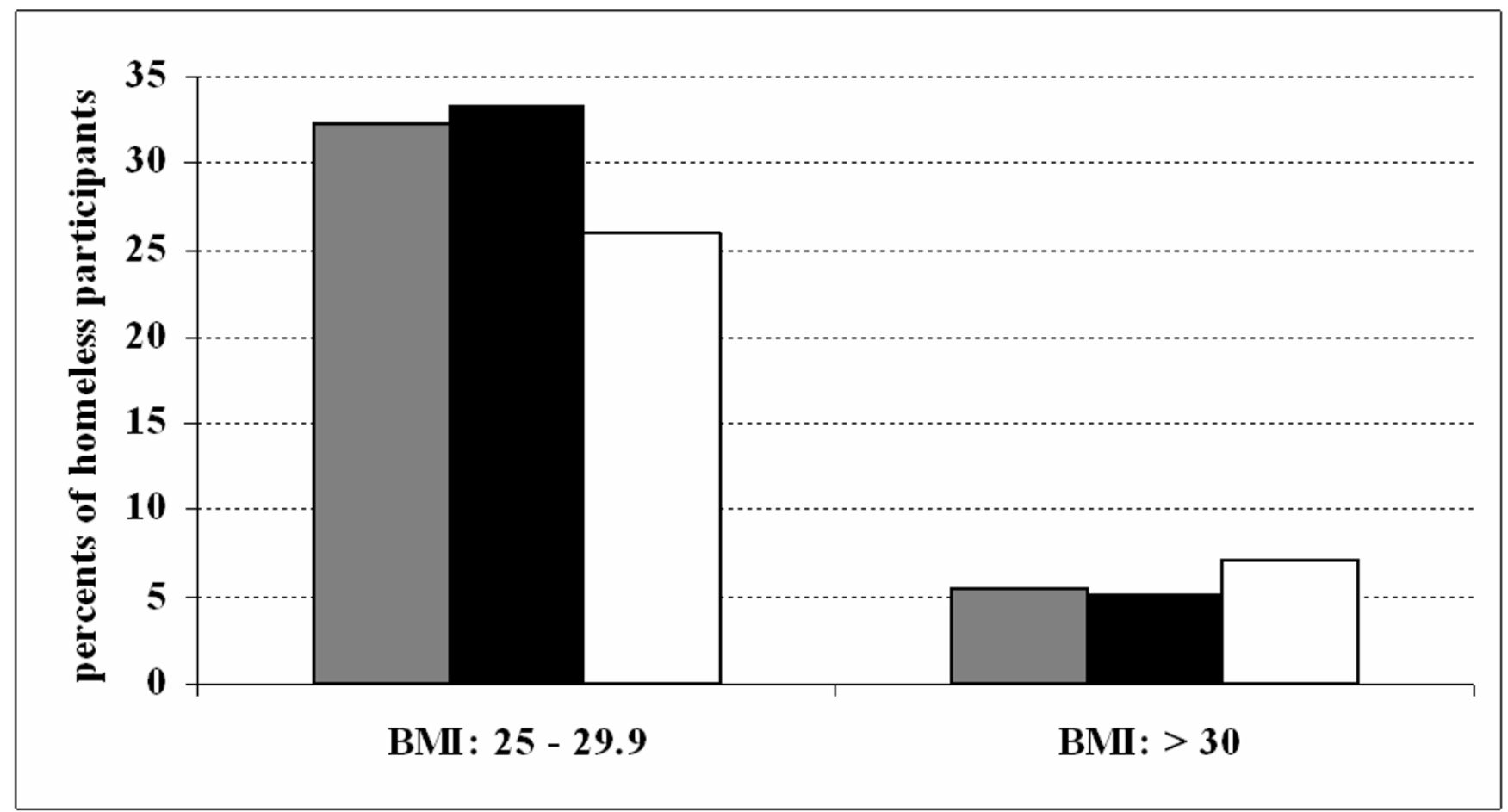

Figure I

Prevalence of overweight and obesity in the homeless population. Grey bars: total study population ( $\mathrm{n}=20 \mathrm{I}$ ); black bars: males ( $n=174)$; white bars: females $(n=27)$. Overweight: BMI $25-29.9$ kg/m²; obesity: BMI > $30 \mathrm{~kg} / \mathrm{m}^{2}$. 


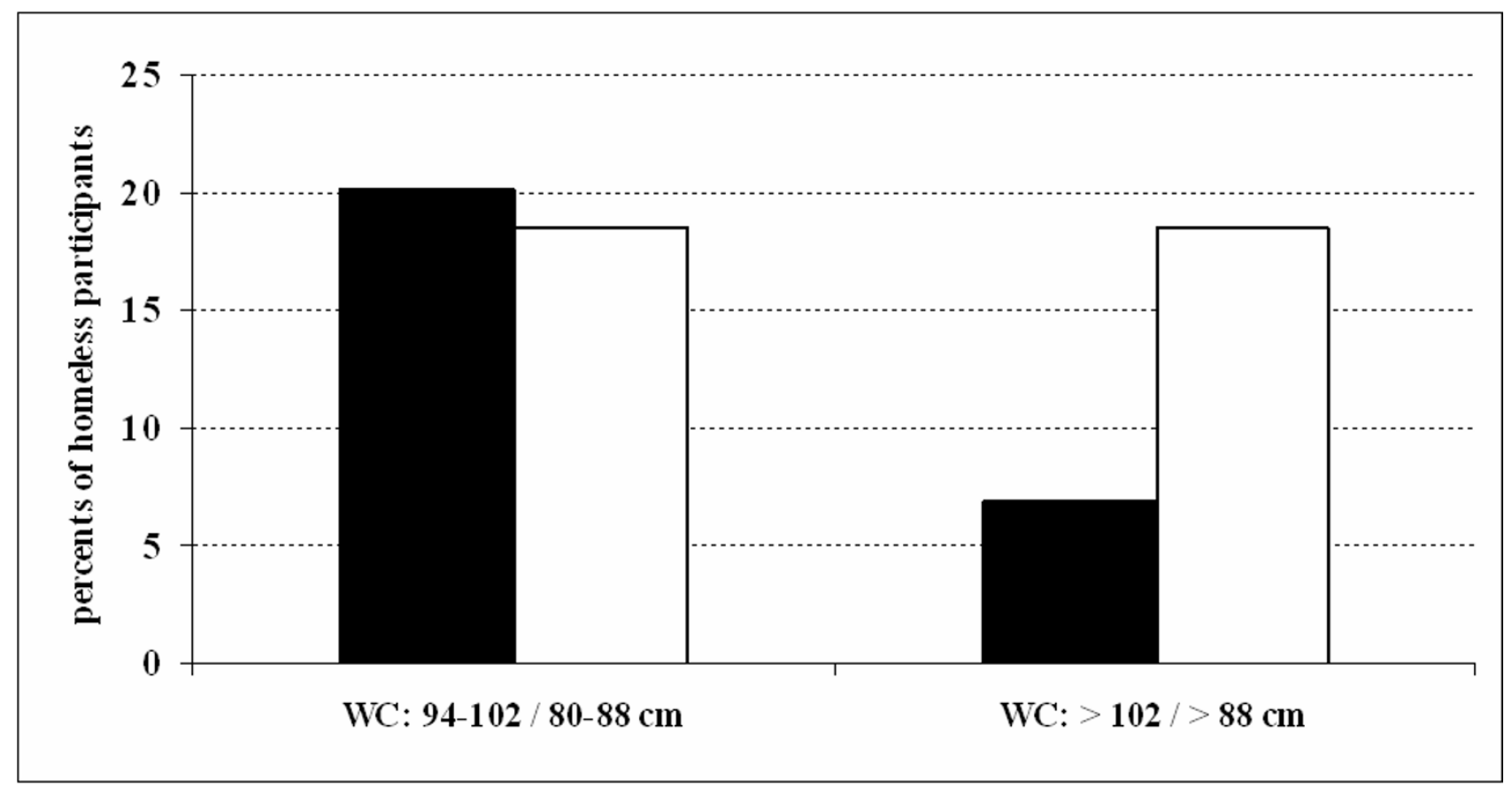

\section{Figure 2}

Prevalence of increased and very high waist circumference in the homeless population. Black bars: males $(\mathrm{n}=$ 174); white bars: females $(n=27)$. Increased waist circumference: WC $94-102 \mathrm{~cm}$ for men, $80-88 \mathrm{~cm}$ for women; very high waist circumference: $W C>102 \mathrm{~cm}$ for men, $>88 \mathrm{~cm}$ for women.

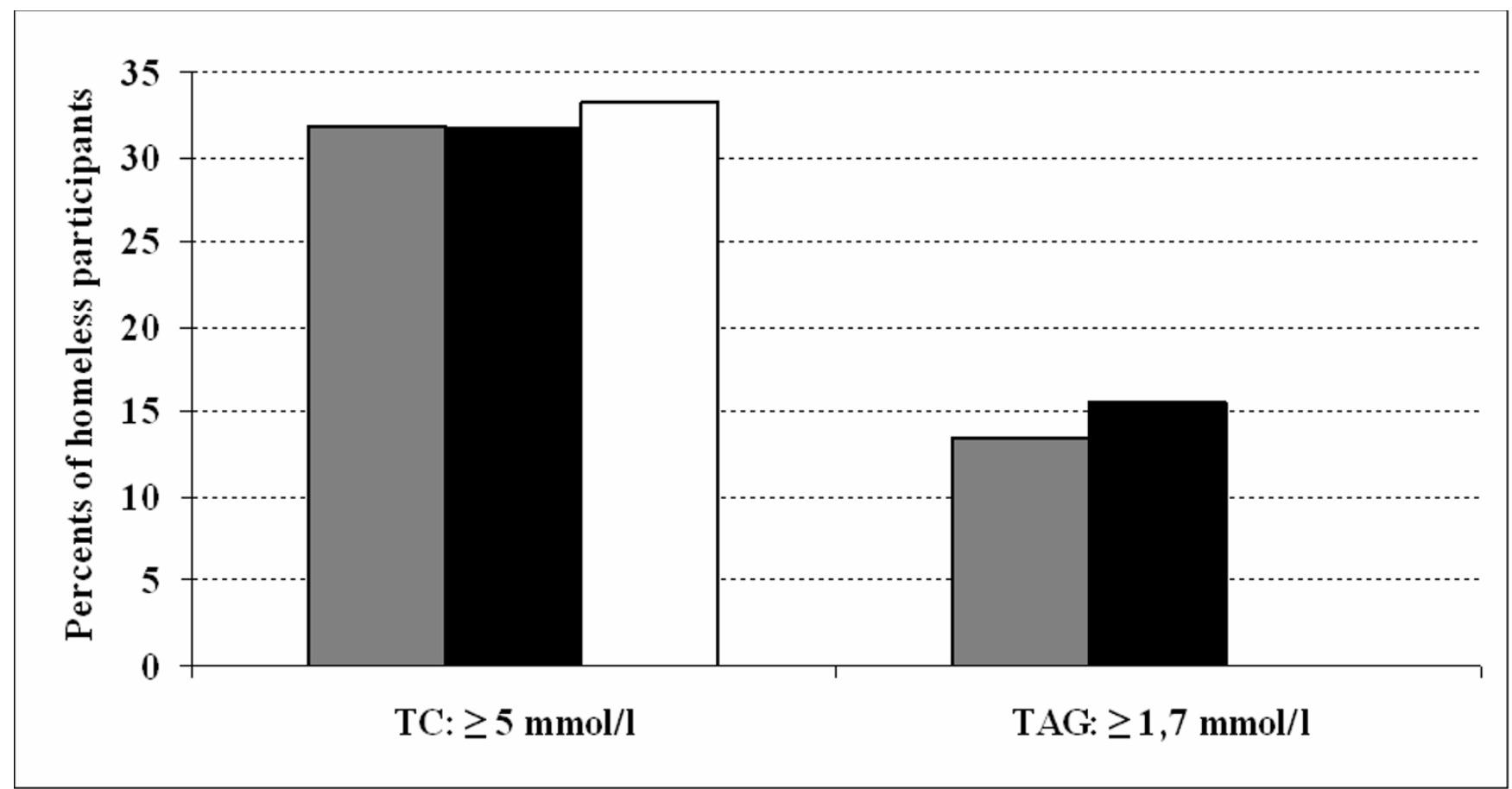

\section{Figure 3}

Prevalence of increased total cholesterol and triacylglyceride level in the homeless population. Grey bars: total study population $(n=20 \mathrm{I})$; black bars: males $(n=174)$; white bars: females $(n=27)$. Increased total cholesterol: TC $\geq 5$ mmol/ I; increased triacylglyceride level: TAG $\geq 1.7 \mathrm{mmol} / \mathrm{l}$. 


\section{Authors' contributions}

DK coordinated the study, supervised the research group, contributed to the study design, data collection, analysis and interpretation, and helped to draft the manuscript. VL participated in statistical analysis, especially with the data comparisons and made essential contributions to data interpretation. VA made a substantial contribution to data acquisition and participated in the statistical analysis. PD participated in the conception and design of the study, data interpretation, and drafting of the manuscript. JR participated in data collection, and assisted in drafting the manuscript. MA participated in the conception of the study, and data interpretation. All authors read and approved the final manuscript.

\section{Acknowledgements}

The authors are grateful to L. Hemrová and L. Fučíková, from Naděje, for collecting the blood samples. The study was funded by the research program of the Third Faculty of Medicine, Charles University No. MSM 0021620814 , and the Internal Grant Agency of the Ministry of Health of the Czech Republic NR/8049-3.

\section{References}

I. Obadalová M: Approach to housing of socially at risk population groups (in Czech). Research Institute for Labour and Social Affairs, Prague 200I.

2. Hradecký I, Kosová P, Myšáková M, Omelková L, Sedláček P: Census of Homeless in Prague, final report (in Czech). MCSSP 2004 [http://www.mcssp.cz/oav texty.php]

3. Dragomirecká E, Kubisová D, Anděl M: Mental health of Czech homeless (in Czech). Psychiatrie 2004, 8:275-280.

4. Trnka L, Kantorová Z, Krejbich F: Homeless and tuberculosis (in Czech). Zdravotnické noviny, Lékařské listy 2003, 33:22-25.

5. Brožová J, Daňková Š, Chudobová M, Kamberská Z, Lexová P: Women and men in numbers of health statistics (in Czech). Institute of Health Information and Statistics of the Czech Republic, Prague, Czech Republic 2004. (ISBN 80-7280-262-3)

6. Barrow MS, Herman DB, Cordova P, Struening EL: Mortality among homeless shelter residents in New York City. Am J Public Health 1999, 89(4):529-534.

7. Hwang SW, Orav EJ, O'Connell JJ, Lebow LM, Brennan TA: Causes of death in homeless adults in Boston. Ann Intern Med 1997, 1 26:625-628.

8. Connor SE, Herbert MI, Neal SM, Williams JT: Smoking cessation in homeless population: there is a will, but is there a way? J Gen Intern Med 2002, I7(5):369-372.

9. Butler J, Okuyemi KS, Jean S, Nazir N, Ahluwalia JS, Resnicow K: Smoking characteristics of a homeless population. Substance abuse 2002, 23(4):223-23।.

10. Hwang SW, Bugeja AL: Barriers to appropriate diabetes management among homeless persons in Toronto. Can Med Assoc J 2000, I63(2):161-165.

II. Langnase K, Muller MJ: Nutrition and health in an adult urban homeless population in Germany. Public Health Nutr 200I, 4(3):805-8I I.

12. Luder E, Ceysens-Okada E, Koren-Roth A, Martinez-Weber C: Health and nutrition survey in a group of urban homeless adults. J Am Diet Assoc 1990, 90( I 0): 1387-1492.

13. Szerlip MI, Szerlip HM: Identification of cardiovascular risk factors in homeless adults. Am J Med Sci 2002, 324(5):243-246.

14. Lee TC, Hanlon JG, Ben-David J, Booth GL, Cantor WJ, Connelly PW, Hwang SW: Risk factors for cardiovascular disease in homeless adults. Circulation 2005, I I I(20):2629-2635.

15. World Health Organization (WHO): Physical Status: The use and interpretation of anthropometry. In Report of the WHO expert committee. WHO technical report series, No. 854 Geneva: WHO; 1995.

16. Despres JP, Lemieux I, Prud'homme D: Treatment of obesity: need to focus on high risk abdominally obese patients. $B M J$ 200I, 322:716-720.
17. De Backer G, Ambrosioni E, Borch-Johnsen K, Brotons C, Cifkova R, Dallongeville J, Ebrahim S, Faergeman O, Graham I, Mancia G, et al.: European Guidelines on Cardiovascular Disease Prevention in Clinical Practice. New European Journal of Cardiovascular Prevention and Rehabilitation 2003, I0(SuppI I):SI-S78

18. Cífková R, Škodová Z: Longitudinal trends in major cardiovascular disease risk factors in the Czech population (in Czech). Cas Lek Cesk 2004, I 43(4):219-226.

19. Snyder LD, Eisner MD: Obstructive lung disease among the urban homeless. Chest 2004, I 25(5): I719-1725.

20. Malmauret L, Leblanc J, Cuvelier I, Verger P: Dietary intakes and vitamin status of a sample of homeless people in Paris. Eur J Clin Nutr 2002, 56(4):3 I3-320.

21. Escobedo LG, Anda RF, Smith PF, Remington PL, Mast EE: Sociodemographic characteristics of cigarette smoking initiation in the United States. Implications for smoking prevention policy. JAMA 1990, 264:1550-1555.

22. Wagenknecht LE, Perkins LL, Cutter GR, Sidney S, Burke GL, Manolio TA, Jacobs DR Jr, Liu KA, Friedman GD, Hughes GH, et al.: Cigarette smoking behavior is strongly related to educational status: the CARDIA study. Prev Med 1990, 19(2):158-169.

23. Sullivan MA, Covey LS: Current perspectives on smoking cessation among substance abusers. Curr Psychiatry Rep 2002, 4(5):388-396.

24. Fichter MM, Quadflieg N: Prevalence of mental illness in homeless men in Munich, German: results from a representative sample. Acta Psychiatrica Scandinavica 200I, 103:94- 104.

25. Kovess V, Mangin-Lazarus C: The prevalence of psychiatric disorders and use of care by homeless people in Paris. Soc Psychiatry Psychiatr Epidemiol 1999, 34:580-587.

26. Aloot $C B$, Vredevoe DL, Brecht ML: Evaluation of high-risk smoking practices used by the homeless. Cancer Nurs 1993, 16(2): $123-130$.

27. Luder E, Boey E, Buchalter B, Martinez-Weber C: Assessment of the nutritional status of urban homeless adults. Public Health Reports 1989, 104:45I-457.

28. Yagalla MV, Hoerr SL, Song WO, Enas E, Garg A: Relationship of diet, abdominal obesity, and physical activity to plasma lipoprotein levels in Asian Indian physicians residing in the United States. J Am Diet Assoc 1996, 96(3):257-26I.

29. Merchant AT, Anand SS, Vuksan V, Jacobs R, Davis B, Teo K, Yusuf S: Protein Intake Is Inversely Associated with Abdominal Obesity in a Multi-Ethnic Population. J Nutr 1995, 135:1196-1201.

\section{Pre-publication history}

The pre-publication history for this paper can be accessed here:

\section{http://www.biomedcentral.com/1471-2458/7/51/prepub}

Publish with Biomed Central and every scientist can read your work free of charge

"BioMed Central will be the most significant development for disseminating the results of biomedical research in our lifetime. "

Sir Paul Nurse, Cancer Research UK

Your research papers will be:

- available free of charge to the entire biomedical community

- peer reviewed and published immediately upon acceptance

- cited in PubMed and archived on PubMed Central

- yours - you keep the copyright

Submit your manuscript here:

http://www.biomedcentral.com/info/publishing_adv.asp

BiolMedcentral 